\title{
EDITORIAL El Mañana es la Edad de la Madera
}

Hilario Hernández-Gurruchaga ${ }^{\dagger}$

\begin{abstract}
$M$ aravillosa estructura vegetal, renovable, de fácil transformación, bella, cálida y apropiada para los más diversos usos, la madera ha servido a la humanidad desde sus orígenes. En forma permanente y continua ha estado presente a lo largo de la historia de las civilizaciones en la casi totalidad de las actividades del hombre.
\end{abstract}

Pero, no sólo debemos consideración a su pasado; los requerimientos actuales y los avances de la ciencia y la tecnología proyectan a la madera como uno de los materiales del futuro. Es probablemente la única materia prima renovable que se utiliza a gran escala y cuyo aprovechamiento no daña al medio ambiente. Es un producto ecológico y económico; producida por la naturaleza y transformable con mínimo costo de energía; finalizando su ciclo de vida, la madera se recicla o se revaloriza sin efectos de contaminación. Adicionalmente los avances tecnológicos han permitido mejorar las prioridades de sus productos derivados, han creado nuevos productos y ampliado su esfera de aplicación, y se han complementado con otros materiales para mejorar sus prestaciones. Para un mundo de necesario desarrollo sustentable, EL MAÑANA ES LA EDAD DE LA MADERA.

Nuestro país, y particularmente la VIII Región tienen excepcionales condiciones para enfrentar el presente y el auspicioso futuro de la madera. Chile posee casi 11 millones de hectáreas de bosques productivos y cerca de 34 millones de hectáreas potenciales ${ }^{1}$. Ello, conjuntamente con una decidida política de Estado y una fuerte dinámica empresarial, han permitido que el sector forestal se constituya en uno de los pilares de la actual estrategia nacional de desarrollo basada en una inserción exportadora intensiva en recursos naturales y materias primas, recursos que han constituido hoy día su principal ventaja comparativa.

Sin embargo, en el objetivo de continuar el proceso nacional de desarrollo, existen múltiples y variados sintomas que señalan que la actual estrategia comercial caracterizada por la exportación de materias primas y "commodities" con fuerte componente de internacionalización de los activos de las empresas involucradas, debe ceder paso a una opción estratégica de inserción externa basada en la industrialización y el procesamiento de los recursos naturales. Para una segunda fase exportadora del país debe establecer una estrategia de desarrollo basado no tanto en la extracción de recursos naturales, como hasta ahora, sino a partir de los recursos naturales y de las actividades que naturalmente tienden a formarse y aglutinarse en torno a ellos (clusters). Es esta una perspectiva que asume el potencial de aprendizaje tecnológico y productivo existente entorno a las principales cadenas exportadoras chilenas, para desarrollar a partir de éstas un conjunto de actividades productivas a través de encadenamientos "hacia adelante" (procesamiento de productos de mayor valor agregado) encadenamientos "hacia atrás" (insumos, bienes en equipo, servicios especializados) y "hacia el lado" (actividades que aprovechen las inversiones y el "know how" desarrollados a partir de la actividad principal).

El desafío de esta nueva estrategia implica una organización del trabajo con mayor calificación de las tareas y requerimientos de mayor proximidad espacial entre los sujetos participantes, por lo que es una clara opción de desarrollo regional, pero asimismo, constituye una estrategia que requiere estimular las interacciones de los diferentes agentes y actores que existen tras el desarrollo de los "clusters" (universidades,

\footnotetext{
† Dedicada a la memoria del exRector UBB, Profesor Hilario HERNÁNDEZ-GURRUCHAGA (1936-2010). Concepción, Chile Publicada originalmente en 1998, como Editorial de la edición de lanzamiento de la revista Maderas-Cienc Tecnol 1(1):3-4.

${ }^{1}$ Según INFOR (2008) casi 16 millones de hectáreas de bosques productivos y casi 30 millones de hectáreas potenciales. INFOR. 2008. Anuario Forestal. Boletín estadístico $\mathrm{N}^{\circ} 121$ (Nota del Editor).
} 
empresas, centros de investigación y de transferencia tecnológica, agencias públicas de promoción), así como la internalización y difusión de experiencias e información sobre el tratamiento de los productos, los requerimientos externos y los mecanismos de comercialización y financiamiento.

Las universidades y particularmente las regionales, por su condición de "nodos de inteligencia social" deben cumplir un rol protagónico en el enfrentamiento de estos desafíos. Deben cumplir un papel esencial en la generación del conocimiento pertinente a las necesidades estratégicas de desarrollo de los "clusters", para la formación de cuadros profesionales y en el intercambio de académicos y estudiantes con entidades extranjeras que permitan estimular la circulación de información estratégica entre los actores y las empresas. En su condición de corporación estatal y consciente del deber que la asiste, la Universidad del Bío-Bío ha definido su misión y comprometido su accionar en el objetivo de servir al desarrollo del país y, particularmente, de la región en la que se inserta. Consecuentemente, el área de la Madera ha constituido desde siempre una de sus líneas prioritarias de desarrollo y de entrega.

En este propósito se inscribe la creación de la revista Maderas: Ciencia y Tecnología. Cumpliendo a través de este órgano de comunicación con el deber de dar existencia social al conocimiento, nos proponemos que esta revista sea un puente de transferencia hacia el aparato productivo y un insumo esencial en la formación de graduados y posgraduados en ciencias y tecnología de la madera, en el fundamental objetivo de colaborar en la conformación de los conocimientos y de los profesionales que en la hora actual y futura nuestro país y nuestra región requieren.

En el superior objetivo de transformar el conocimiento en bien social, la universidad del Bío-Bío inicia la publicación Maderas: Ciencia y Tecnología y ofrece este canal de comunicación a la participación de la comunidad científica y profesional de la madera, en el afán de comunicar sus inquietudes y logros a la sociedad toda, para su mejor futuro. 